\title{
INTERNATIONAL WATERSHED TECHNOLOGY: IMPROVING WATER QUALITY AND QUANTITY AT THE LOCAL, BASIN, AND REGIONAL SCALES
}

\author{
E. W. Tollner, K. R. Douglas-Mankin
}

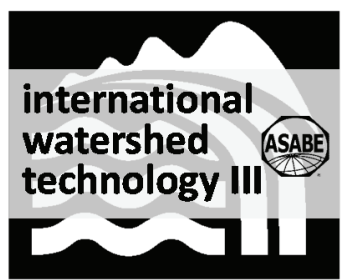

\begin{abstract}
This article introduces the five papers in the "International Watershed Technology" collection. These papers were selected from 60 technical presentations at the fifth biennial ASABE 21st Century Watershed Technology Conference and Workshop: Improving the Quality of Water Resources at Local, Basin, and Regional Scales, held in Quito, Ecuador, on 3-9 December 2016. The conference focused on solving spatial and temporal water quality and quantity problems and addressed topics such as watershed management in developing countries, aquatic ecology and ecohydrology, ecosystem services, climate change mitigation strategies, flood forecasting, remote sensing, and water resource policy and management. While diverse, the presentation topics reflected the continuing evolution of the "data mining" and "big data" themes of past conferences related to geospatial data applications, with increasing emphasis on practical solutions. The papers selected for this collection represent applications of spatial data analyses toward practical ends with a theme of "tools and techniques for sustainability." The papers address a range of topics, including the matching of crops with water availability, and assessing the environmental impacts of agricultural production. The papers identify some of the latest tools and techniques for improving sustainability in watershed resource management that are relevant to both developing and developed countries.
\end{abstract}

Keywords. Data mining, Modeling, Research, Sustainability, Water quality, Water supply.

W atershed science and engineering have advanced rapidly in recent decades with the development and application of expanded knowledge and cutting-edge technologies in environmental monitoring, geospatial data processing, modeling, and analysis. While these approaches have solved many critical problems, many more challenges remain.

Advances in international watershed technology have been summarized in two recent American Society of Agricultural and Biological Engineers (ASABE) special collections (Tollner and Douglas-Mankin, 2013, 2016) that resulted from the third and fourth in a series of international conferences on the topic. Efforts to increase exchange of the latest international research and technology related to sustainable watershed resource management continued with the fifth biennial ASABE 21st Century Watershed Technology Conference and Workshop: Improving Water Quality and the Environment. The conference received broad sponsorship from ASABE; the Texas Institute for Applied Environ-

Submitted for review in October 2017 as manuscript number NRES 12687; approved for publication as part of the "International Watershed Technology" collection by the Natural Resources \& Environmental Systems Community of ASABE in November 2017.

The authors are Ernest W. Tollner, ASABE Fellow, Professor, Department of Biological and Agricultural Engineering, University of Georgia, Athens, Georgia; Kyle R. Douglas-Mankin, ASABE Member, Supervisory Hydrologist, U.S. Geological Survey, Albuquerque, New Mexico. Corresponding author: Ernest W. Tollner, 620 Driftmier Engineering Center, University of Georgia, Athens, GA 30602; phone: 706542-3047; e-mail: btollner@engr.uga.edu. mental Research (TiAER) at Tarleton State University; Universidad Regional Amazonica (IKIAM), Quito, Ecuador; Secretary of Education, Office of Science, Technology, and Innovation (SENESCYT), Quito, Ecuador; the University of Florida; and the USDA-ARS. Professionals working in watershed technology and related areas met in Quito, Ecuador, on 3-9 December 2016 to exchange information on science, applications, and developments in watershed science and technology. The meeting papers are available in the ASABE Technical Library (http://elibrary.asabe.org) and may be located with a search of the conference papers.

The presentations included a breadth of quality work relating to applications of agricultural and biological engineering in developing and developed countries to solve practical problems. Five papers from the conference were selected for inclusion in this collection as exemplary contributions to advancing watershed technology and science. This introductory article introduces and summarizes these papers.

\section{WATERSHED TECHNOLOGY TOOLS AND TECHNIQUES FOR SUSTAINABILITY}

Carrera-Villacrés et al. (2017) presented the development and application of a fog catcher system for water supplies in the Andean region of Ecuador. The concept arose from a thorough literature review and analyses of soil physiographic characteristics, cropping patterns, soil physical properties, and soil chemical properties. The work provides others around the world with a basis for examining and implementing a concept for water capture in this era of water shortage. 
Ochoa et al. (2017) performed a study to determine where coffee can be most profitability grown in Ecuador. They exhaustively analyzed conditions on some 70 farms with demographic surveys, physiographic analyses, soil physical analyses, and soil chemical analyses. Their analyses provided a basis for identifying the regions where coffee was most profitable or where other more profitable crops should be considered. From both studies, the methods used appear to be promising for similar analyses in other parts of the world.

Another example of potentially beneficial approaches for improving life around the world comes from the U.S. and relates to shellfish production. Shellfish are an important component of the diet in many parts of the world, but shellfish sanitation is an ongoing challenge. Conte and Ahmadi (2017) analyzed 68,000 water samples collected over 25 years from 2,400 sampling stations in 107 shellfish production areas in an attempt to find a strategy for early identification of fecal contamination in production regions. They developed a model, called Mermaid, that advances the technology for earlier delineation of contaminated shellfish. This will allow shellfish products from contaminated regions to be tracked and possibly excluded from harvest. Standard most probable number (MPN) approaches, similar to those used in evaluating waste treatment plant effluents, provided the basis for the approach. The techniques were straightforward and can be implemented in other parts of the world.

Turning to developed countries and the problems that population density imposes on resource sustainability, spatial data are routinely being used for assessing the impacts of production practices and climate change on quality of life. The concept of pay-for-performance (PFP) is being considered as a way to induce producers to opt for best management practices (BMPs) that are proven to reduce pollutant contamination downstream. Muenich et al. (2017) reviewed the PFP concept, noting that the establishment of a robust basis for convincing cause-effect relationships in BMP versus consistent PFP results can be problematic. Muenich et al. (2017) used SWAT to assess BMPs for improving runoff quality in a basin draining into Lake Erie. Other studies (e.g., Lee et al., 2017, discussed below) focused on the drainage areas of other lakes in the Great Lakes system, as well as Chesapeake Bay and other locations across the U.S. The lack of consistency between upstream BMP implementation and downstream water quality results is currently the primary roadblock to widespread PFP implementation. The 2014 Watershed Technology Conference (Tollner and DouglasMankin, 2016) highlighted similar work in New Zealand, where the concept is now used to determine practices that farmers and ranchers may employ on their land.

Lee et al. (2017) examined a specific BMP in detail, i.e., the use of winter cover crops in reducing nitrate loads in Chesapeake Bay. They suggested that climate change may exacerbate the degradation of water quality in Chesapeake Bay. The thrust of their study was to assess the benefits of winter cover crops in decreasing the nitrate nitrogen loading in the bay. Future simulated climates were conducive to winter cover crops. The SWAT model predicted a $58 \%$ increase in biomass and a $48 \%$ reduction in nitrate loadings into the bay from implementation of winter cover crops under future climate scenarios.

\section{Concluding Statements}

This article introduces the five papers selected for the "International Watershed Technology" collection. The papers generally spanned a theme of "tools and techniques for sustainability," and they identified some of the latest tools and techniques for improving sustainability in watershed resource management that are relevant to both developing and developed countries.

There is much work yet to be undertaken to provide needed clarity on BMP-PFP relationships. We can safely say that a significant area of current research in developed countries involves how to refine BMP-PFP relationships and make them more robust with a variety of conservation and sustainability approaches. Similarly, there is much work to be done in developing countries on creative ways to use and apply the available natural resources and ecological services. The 2016 Watershed Technology Conference and this collection identified several cases where local intellectual capital is developing to a point where constructive dialog can occur among developing countries around the world.

\section{REFERENCES}

Carrera-Villacrés, D. V., Robalino, I. C., Rodríguez, F. F., Sandoval, W. R., Hidalgo, D. L., \& Toulkeridis, T. (2017). An innovative fog catcher system applied in the Andean communities of Ecuador. Trans. ASABE, 60(6), 1917-1923. https://doi.org/10.13031/trans.12368

Conte, F. S., \& Ahmadi., A. (2017). Application of the Mermaid shellfish sanitation model using a Virginia shellfish dataset during the transition from a multiple tube test to the membrane filtration. Appl. Eng. Agric., 33(6), 835-839. https://doi.org/10.13031/aea.12355

Lee, S., Sadeghi, A. M., Yeo, I.-Y., McCarty, G. W., \& Hively, W. D. (2017). Assessing the impacts of future climate conditions on the effectiveness of winter cover crops in reducing nitrate loads into the Chesapeake Bay watersheds using the SWAT model. Trans. ASABE, 60(6), 1939-1955. https://doi.org/10.13031/trans.12390

Muenich, R. L., Kalcic, M. M., Winsten, J., Fisher, K., Day, M., O’Neil, G., Wang, Y.-C. \& Scavia, D. (2017). Pay-forperformance conservation using SWAT highlights need for field-level agricultural conservation. Trans. ASABE, 60(6), 1925-1937. https://doi.org/10.13031/trans.12379

Ochoa, P. A., Chamba, Y., \& Capa, D. (2017). Estimation of potential areas for coffee production: Methodology by regions with limited data. Appl. Eng. Agric., 33(6), 841-848. https://doi.org/10.13031/aea.12354

Tollner, E. W., \& Douglas-Mankin, K. R. (2013). International watershed technology: Solving spatial and temporal water quality and quantity problems. Trans. ASABE, 56(6), 1353-1356. https://doi.org/10.13031/trans.56.10535

Tollner, E. W., \& Douglas-Mankin, K. R. (2016). International watershed technology: Improving water quality and the environment. Trans. ASABE, 59(2), 535-536. https://doi.org/10.13031/trans.59.11735 